\title{
Digital Transformation in Asset-intensive Businesses: Lessons Learned from the Metals and Mining Industry
}

\author{
Shan Gao \\ Aalto University, Outotec \\ shan.2.gao@aalto.fi
}

\author{
Esko Hakanen \\ Aalto University \\ esko.hakanen@aalto.fi
}

\author{
Pekka Töytäri \\ Aalto University \\ pekka.toytari@aalto.fi
}

\author{
Risto Rajala \\ Aalto University \\ risto.rajala@aalto.fi
}

\begin{abstract}
Digital transformation shapes business operations across industries. The present study investigates the challenges of this transformation in asset-intensive businesses. Based on a qualitative case study in the metals and mining industry, the study explores the early attempts to implement digital technologyenabled changes in the inter-organizational exchange as part of firms' business models in their business ecosystems. In particular, the study identifies the challenges related to the ways firms in the metals and mining industry manage to seize the opportunities that digital technologies provide for their business operations. The challenges include firms' lack of capabilities to change, goal ambiguity, technological constraints and external constraints. The findings contribute to the discussion of digital transformation as a technology-enabled strategic change and provide suggestions for business practitioners about factors that can impede the realization of this transformation.
\end{abstract}

Keyword: digitalization, dynamic capabilities, organizational change, metals, mining

\section{Introduction}

"It's more about the transformation of a company than it is about the implementation of a specific solution." (Senior Managing Director, I1).

Digital transformation is shaping business operations across industries at a fast pace. Defined as "a new development in the use of digital artifacts, systems, and symbols within and around organizations" [11:20], it induces radical changes to business models in industrial ecosystems and reshapes business practices at the institutional level. Research has elaborated positive attitudes toward the gamechanging effect to value creation by the industrial digital transformation [25, 38, 44]. Thus, scholars have argued that digital transformation is an inevitable trend for a vast array of industries [17, 37, 38]. Digital transformation has been presented as a strategic opportunity that enables new services $[33,38]$ and value creation opportunities [25, 41] for firms.
Several success stories underline the potential of digital transformation [29, 40, 41, 44]. Such success stories across industries have spurred a common public belief: digital transformation is achievable, and once done, business value will follow. However, the reality seems more complicated. The practical implementation of digital transformation has lagged behind in some industry contexts. For instance, the digital intensity index (DII) published by the European Commission indicates that in 2017, only around 10\% of the enterprises in the metals sector were with high DII, whereas in the ICT sector the corresponding figure was well above 60\% [24]. Among the manufacturing sectors, the lowest DII percentages were found among metals and textiles subsectors. Surprisingly, even furniture manufacturers and coke, petroleum, chemical, and plastics producers had higher DII scores (20\%) [24]. So, despite the high prospect of digital transformation, the advances have been slow in the manufacturing sector.

Such industry-wide deficiencies indicate some notable pitfalls in the digital transformation process. While the implementation of IT or software upgrades among multiple parties is always complicated [36, 39], digital transformation goes far beyond, as it can transform the whole business via the adoption of digital technologies [29, 37, 44, 54]. Furthermore, technological innovations tend to require subsequent business model innovations [6]. Such changes require dynamic capabilities from the organizations [30, 43]. Either the metals and mining industry firms have not possessed the necessary competencies, or there are other common challenges in the process.

Such challenges in the digital transformation process have not been studied comprehensively. Instead, studies have focused on the barriers and failures in ICT project implementation [5, 50]. In addition, the literature is rich in studies on business model transformation [6, 13, 26]. However, more research is needed to unravel the far-reaching and multifaceted consequences of digital transformation. This study attempts to fill this gap by selecting the context of a traditional, asset-intensive industry, where the phenomena reflecting the transformation challenges are expected to be more evident. 
During 2016, we conducted a series of interviews globally regarding the understanding and future trends of digital transformation for the metals and mining industry sector. Our purpose was to gain an in-depth understanding of challenges that may obstruct digital transformation across the industry. One common finding was that against their expectations, the majority of the informants had negative experiences about the various transformation phases, as well as doubts about the possible value brought by the transformation.

The following research questions were posed: how capable are the firms in asset-intensive businesses to meet the challenges of digitalization? Why have the firms found the digital transformation so challenging? Learning from these, we make suggestions on what should be done to overcome the barriers. Also, we identify factors that contribute to successful digital transformation.

This study aims at improving the current understanding of digital transformation while focusing on the reasons the full potential of the technologies is not delivered in the industrial context. In doing so, the study contributes to the discussion of the factors affecting the digital transformation process.

\section{Background for the Research}

As its definition illustrates, digital transformation creates new artifacts within and between organizations [11]. Thus, higher interoperability and adjustability among different systems have significantly impacted, for instance, the service offerings between the firms $[15,33]$. Digital transformation enables more diverse and more cost-efficient access to data, which firms can use to improve their offerings or allows new parties to partake in the existing processes [33]. In practice, digital transformation can support new value creation mechanisms among industry firms [29, 44], but also demands strategic renewal from the firms [31,52].

\subsection{Digital transformation}

Digital transformation of the metals and mining industry has been discussed in various institutional reports in terms of identified targets, opportunities and estimated gains [23, 46, 52]. The studies have all referred to the industrial challenges such as aging workforce, declining ore grade and weakened demand on base metals [34, 52]. Besides, trends such as circular economy [44], metal substitution [1, 45], resource nationalism [52], and intensifying sustainability regulations $[12,45]$ are pressuring the metals and mining companies toward a change. In addition, emerging business opportunities, such as the rising demand for EV battery materials [51], may require a more collaborative approach and more emphasis on the ecosystem-level benefits [29, 44].

The technological advancements have made the complex and adaptive nature of the organizational networks more critical. Now, the fleet of assets can be designed for adaptive connectivity [10] and unknown future use cases [54]. In contrast, the traditional production planning and control systems have been designed to follow a predefined path, reducing variation and adjustments [4]. This fundamental difference in the system design calls for further research to understand its effects on the business models of industry actors.

Implementing changes in such a complex environment is challenging. Digital transformation was brought up at strategic and operational level by the major global firms operating in this industry, with a good will that digital transformation will help overcome the aforementioned challenges and refine their value creation $[22,23,52]$. However, in terms of actual progress, this industry is considered to have been left behind in the digital transformation[24].

\subsection{Strategic renewal upon digital transformation}

Digital transformation enables new ways of value creation based on utilizing previously unexploited resources in the business ecosystem. However, the utilization of those resources often requires a change in the firms' value-creating capabilities. The dynamic capabilities perspective [48] suggests that the firms maintain their competitiveness by targeted modification of their resources and capabilities. Dynamic capabilities are defined as organizational routines [20] to keep the firm's resource and capability base relevant [48] by matching and creating market change [20]. The inner workings of dynamic capabilities are illustrated by activities such as environmental scanning, evaluation, and implementation of new operational capabilities through a process of sensing, seizing and transforming the firm's resource and capability portfolio [20].

Firms differ in their dynamic capabilities. The firms have a heterogenous capacity to detect opportunities (such as those created by the digital transformation), evaluate the potential of the opportunities, and finally develop, integrate, and possibly abandon irrelevant capabilities and resources. A source of variation in the outcomes of dynamic capabilities relates to the microfoundations $[2,31]$ of dynamic capabilities: managers' cognitive frames guide the application of dynamic capabilities and hence lead to heterogeneous outcomes. 
Digital transformation also increases the rate of change of the industrial markets [3]. Market change velocity often oscillates between long periods of stability and short bursts of radical change [27]. Recently, digital transformation has started driving an accelerated change, and many industrial actors may lack the agility to respond. One source of inertia could be the lack of dynamic capabilities.

Even if present, the firm's dynamic capabilities may also fail at any stage of the sensing, seizing and transforming. Even if the opportunity is seen and appreciated by a firm, there is a challenging need to concurrently develop the complementary capabilities in different parts of the organization.

The change induced by digital transformation has a wide-spread impact on firm processes and structures. Digitally enabled value creation integrates the resources and capabilities of multiple organizational units (such as IT, Operations, R\&D, Sales and Marketing, Legal) by creating new boundary-spanning processes and other dependencies. Specifically, there are important dependencies between resources and capabilities. Some resources or capabilities may require the presence of other resources or capabilities to create value. For instance, production generated data need to be securely and cost effectively transmitted, managed, and analyzed. The dependencies between capabilities can be unidirectional, where the value of one capability is enhanced by another capability, or bi-directional, where capabilities are only valuable if both capabilities are available together [32, 47]. Many of the capabilities and resources of digital transformation are only valuable if the dependent specialized and cospecialized capabilities [47] are also accessible.

The development and integration of the connected and dependent resources and capabilities may suffer from non-optimal organizational structures, incentives, and deviating cognitive frames. The governance structures and management models have been designed to support different business conditions of the past, and may fail to support the emerging business opportunities. Different functional units may be driven by deviating goals and perceptions [31], and hence may fail in playing their role in the organizationwide change.

\section{Research Methodology}

Our research aims to improve the understanding of the factors that influence the realization of digital transformation in an asset-intensive industry. Thus, selecting qualitative empirical inquiry as the research strategy is justified $[14,18]$. The chosen case study approach [35] allows us to explore the factors that matter in the implementation of digital technologies in the business operations in metals and mining industry. An inductive approach to the data analysis [28] provides the flexibility needed to focus on the factors that emerge in the metals and mining industry. While our study improves the current understanding of factors that affect the digital transformation in the investigated context, it also proposes further research on the topic [18].

The metals and mining industry was chosen as the study context. To the date, the industry has enjoyed a long period of stability, which has encouraged the companies to focus on incremental operational improvements, rather on than radical, disruptive innovations. Now, it seems that the firms have sensed the opportunity to change via digital transformation, although they may have been unable to seize these possibilities or transform the industry.

A total of 40 semi-structured interviews were conducted during 2016 from 27 companies globally. The interviews were conducted either though face-toface discussions or via a telephone call. The selection includes 18 companies that operate in the metals and mining industry. The chosen companies vary significantly in terms of scale, operating location as well as end products. The informants from these companies came mainly from three groups: $\mathrm{CxOs}$, Heads of Operation/Automation, and Heads of IT. We supplemented these metal and mining firms with 9 companies who serve as partners for facilitating digital transformation. The informants of the partners were experienced experts who have been deeply involved in or even play key roles in their customers' digital transformation process. The detailed information of the empirical material is available in Table 1. As shown in the table, one of the informants was interviewed twice, due to his extensive knowledge on the subject.

Our research followed a case study approach [19, 42]. Instead of regarding the firms as individual cases, we defined our case iteratively [42] through the specific and shared contextual setting among the firms [53]. In this setting, we studied the digital transformation process at the firm level. Such approach allowed us to gain detailed insights from the firms involved in the operational level activities and, in turn, to triangulate $[16,53]$ these findings against the views of the partnering firms.

The generated data were coded and analyzed with ATLAS.ti (Version 7). As a comprehensive software package for qualitative analysis, it allows users to perform various processing and analysis on unstructured data. It offers "tools to manage, extract, compare, explore, and reassemble meaningful pieces from large amounts of data" [21:73]. 
Table 1. The empirical material of the study

\begin{tabular}{|c|c|c|c|}
\hline Firm & Profile & $\begin{array}{l}\text { No. of } \\
\text { informants }\end{array}$ & $\begin{array}{l}\text { No. of } \\
\text { interviews }\end{array}$ \\
\hline \multicolumn{4}{|c|}{ Companies that operate in the metals and mining industry } \\
\hline M1 & Operates in multi-continent, produces multiple metals and minerals & 1 & 1 \\
\hline M2 & Operates in multi-continent, produces multiple natural resources & 3 & 3 \\
\hline M3 & Operates in multi-continent, metal producer & 4 & 5 \\
\hline M4 & Operates in multi-continent, gold producer & 1 & 1 \\
\hline M5 & Operates in multi-continent, precious metal producer & 1 & 1 \\
\hline M6 & Operates in China, produces mineral concentrate & 2 & 2 \\
\hline M7 & Operates in Russia & 1 & 1 \\
\hline M8 & Operates in multi-continent, gold producer & 1 & 1 \\
\hline M9 & Operates in Mexico, produces multiple metals & 3 & 3 \\
\hline M10 & Operates in South America, copper producer & 1 & 1 \\
\hline M11 & Operates in India, steel producer & 1 & 1 \\
\hline M12 & Operates in North America, produces iron concentrate and pellets & 1 & 1 \\
\hline M13 & Operates in Russia, precious metal producer & 1 & 1 \\
\hline M14 & Operates in multi-continents, produces industrial minerals & 1 & 1 \\
\hline M15 & Operates in Americas, copper producer & 2 & 2 \\
\hline M16 & Operates in Mexico, produces precious metal & 1 & 1 \\
\hline M17 & Operates in China, steel producer & 1 & 1 \\
\hline M18 & Operates in China, produces multiple metals & 2 & 2 \\
\hline \multicolumn{4}{|c|}{ Partners (providing equipment [OEM]/technology $[\mathrm{T}] /$ platform integration $[\mathrm{I}] /$ consulting $[\mathrm{C}]$ ) } \\
\hline OEM1 & Global firm, supplies mining machineries & 1 & 1 \\
\hline $\mathrm{C} 1$ & Small Australian technology consulting group, specializing on metal and mining technology & 1 & 1 \\
\hline $\mathrm{T} 1$ & Global firm, offers comprehensive ICT solutions including telecom networks and devices & 1 & 1 \\
\hline OEM2 & Global firm, supplies automation equipment and systems to metals and mining companies & 1 & 1 \\
\hline OEM3 & Global firm, supplies equipment and platform solutions to metals and mining companies & 2 & 2 \\
\hline I1 & $\begin{array}{l}\text { Global professional service provider, offers digitalization development and consulting service to } \\
\text { metals and mining companies }\end{array}$ & 2 & 2 \\
\hline $\mathrm{C} 2$ & Small Canadian mining technology consulting group & 1 & 1 \\
\hline C3 & Small metallurgical technology consulting group & 1 & 1 \\
\hline $\mathrm{T} 2$ & A Canadian technology provider for metals and mining companies & 1 & 1 \\
\hline
\end{tabular}

\section{Empirical Findings}

Our case study revealed several lessons learned in the digital transformation journey of the interviewed firms, as presented in Table 2. Our findings converge into four themes. First, we found that, generally, the firms in the industry demonstrated lack of capability to change. They did not recognize the business opportunity or did not appreciate the opportunity enough to implement changes. Second, when the firms decided to change, they had difficulties in determining goals, scoping the undertakings, and sequencing actions. Third, when firms were successfully mobilizing their digital transformation, they met different novel technological constraints. Finally, the external business environment imposed several unexpected constraints on the transformation. In our presentation and following discussion, we focus on those elements of the change that we find novel and context-specific.

\subsection{Lack of capabilities to change}

The firms in metals and mining industry have experienced relatively long periods of incremental change, and hence often lack the desire and the tools to change. "People are always afraid of new technologies or afraid of change, and especially in the mining industry" (Senior Manager, I1). As a result, the firms focus on refining their operational capabilities only. Digital transformation is putting their dynamic capabilities at test. Specifically, our findings emerge from the change of industrial context: industrial firms are exceedingly adopting practices from previously distant industries, such as IT.

The firms lack capability to attract employees with the right expertise on Internet of Things (IoT) or data analysis. The target group of employees finds the industry image unappealing. As a result, firms have been unable to recruit highly skilled individuals to support the change. In addition, divergent views and interests within the firm hinder the changes, since "if a project, that's critical to a company, is not sponsored by the right level of executives in that organization it's gonna fail" (Senior Managing Director, I1). The investments to advanced technologies for the digital transformation are often seen as non-critical, which make them difficult to justify. In order for the firms to actively engage in such projects, it needs to be 
perfectly clear "what is the financial reward for doing those things" (Global Director, M3).

Table 2. The data structure

\begin{tabular}{|c|c|c|}
\hline 1st order & 2nd order & $\begin{array}{c}\text { Aggregate } \\
\text { themes }\end{array}$ \\
\hline $\begin{array}{l}\text { Current ways of working do not suit digital transformation } \\
\text { Firms in the industry are not used to change }\end{array}$ & $\begin{array}{l}\text { Not ready for radical } \\
\text { change }\end{array}$ & \multirow{3}{*}{$\begin{array}{l}\text { Lack of } \\
\text { capabilities to } \\
\text { change }\end{array}$} \\
\hline $\begin{array}{l}\text { The industry is not attractive for employees with the IoT and data expertise } \\
\text { Firms find it difficult to recruit highly skilled workers }\end{array}$ & $\begin{array}{l}\text { Unappealing brand among } \\
\text { target professionals }\end{array}$ & \\
\hline $\begin{array}{l}\text { Lack of support and commitment from top management } \\
\text { Investments to non-critical, advanced technologies seem unappealing } \\
\text { Smaller companies lack the resources (financial and/or expertise) for the } \\
\text { change }\end{array}$ & $\begin{array}{l}\text { Lack of commitment and } \\
\text { investments }\end{array}$ & \\
\hline $\begin{array}{l}\text { Workers are not used to digital tools or collaborative methods } \\
\text { Limited previous experience in transformation projects }\end{array}$ & Outdated skills & \multirow{4}{*}{$\begin{array}{l}\text { Goal } \\
\text { ambiguity }\end{array}$} \\
\hline $\begin{array}{l}\text { Silos and different ways of working inside and between firms } \\
\text { A need for extensive training and different processes to initiate the change }\end{array}$ & $\begin{array}{l}\text { Outdated governance } \\
\text { model }\end{array}$ & \\
\hline $\begin{array}{l}\text { Difficult to define the scope of transformation projects ex-ante } \\
\text { Unforeseen issues are inevitable and they make projects with fixed scope and } \\
\text { price unrealistic } \\
\text { Customers expect too much from the supplier } \\
\text { Misalignment on expectations at different organizational levels }\end{array}$ & $\begin{array}{l}\text { Managing expectations } \\
\text { and scope of change }\end{array}$ & \\
\hline $\begin{array}{l}\text { Transformation projects fail if firms cannot agree on what to focus on } \\
\text { Firms try to change or automatize too many aspects at once } \\
\text { Managers fear that IT projects tend to over-promise and under-deliver, while } \\
\text { exceeding the budget }\end{array}$ & $\begin{array}{l}\text { Unfocused change } \\
\text { initiatives }\end{array}$ & \\
\hline $\begin{array}{l}\text { Difficult (or even prohibited) to get any kind of wireless signal underground } \\
\text { Current interfaces demand human actions to transfer data }\end{array}$ & Connectivity issues & \multirow{6}{*}{$\begin{array}{l}\text { Technological } \\
\text { constraints }\end{array}$} \\
\hline $\begin{array}{l}\text { Breaches in security can result in serious, even fatal, accidents } \\
\text { Operational data is both business sensitive and critical to safety }\end{array}$ & Cyber-security concerns & \\
\hline $\begin{array}{l}\text { The data from sensors are not in standardized form } \\
\text { Non-standard data is challenging to integrate across platforms } \\
\text { Ambiguous stances on the ownership of or access to data } \\
\text { Even if accessible, the datasets may be too complex or scattered }\end{array}$ & Lack of IoT standards & \\
\hline $\begin{array}{l}\text { Most of the technical solutions are not originally designed to mining industry } \\
\text { context } \\
\text { Processes are designed with human operators at mind, automated processes } \\
\text { need to be adjusted to imitate human way of working }\end{array}$ & $\begin{array}{l}\text { Poor applicability of } \\
\text { digital technologies to } \\
\text { current processes }\end{array}$ & \\
\hline $\begin{array}{l}\text { Challenging to equip the machinery with reliable and robust sensors, } \\
\text { delivering high quality measurements } \\
\text { The systems are not mature enough to be self-monitoring }\end{array}$ & Immature technology & \\
\hline $\begin{array}{l}\text { Concerns in the reliability lead to manual monitoring of the digital systems } \\
\text { People are concerned about the reliability, which leads to over-engineering, } \\
\text { redundancies, and upholding legacy systems }\end{array}$ & $\begin{array}{l}\text { Costly redundancy due to } \\
\text { lack of trust in new } \\
\text { systems }\end{array}$ & \\
\hline $\begin{array}{l}\text { Operating environment in the mines (hot, humid, dirty, loud, dangerous) } \\
\text { Most smart, connected devices are not designed to work accurately in such } \\
\text { conditions }\end{array}$ & $\begin{array}{l}\text { Challenging operating } \\
\text { environment }\end{array}$ & \multirow{4}{*}{$\begin{array}{l}\text { External } \\
\text { constraints }\end{array}$} \\
\hline $\begin{array}{l}\text { Safety regulations demand robust, reliable, and safe systems } \\
\text { Firms use their safety policies as an excuse for not making changes }\end{array}$ & $\begin{array}{l}\text { Health and safety } \\
\text { concerns }\end{array}$ & \\
\hline $\begin{array}{l}\text { Labor unions have power to delay or decline transformation projects } \\
\text { Better coordination and harmonization of different policy levels is required }\end{array}$ & Legislation and policies & \\
\hline $\begin{array}{l}\text { Digital transformation can lead to elimination of certain jobs } \\
\text { Long-term investments with considerable employment expectations } \\
\text { Environmental impacts of mining } \\
\text { Secured supply and nationalization of resources }\end{array}$ & Social responsibility & \\
\hline
\end{tabular}




\subsection{Goal ambiguity}

When a firm was willing to pursue digital transformation, it was found that, most often, their organization was unable to support the change. Evidently, the current skill base did not match with the digital transformation demands. Accordingly, the governance and management models were designed to support current business, and the organizational silos impede cooperation.

In addition, targets for the transformation projects tend to be unrealistic, and this difference between the anticipated and the realistic target creates tensions among the stakeholders.

Since the mining industry firms have found it challenging to attract the best talents with vast experience on the digital transformation projects, the firms may lack the capabilities to manage the change. "Getting the expertise, finding people with expertise to build and run those systems. It's a huge challenge." (Chief Data Scientist, OEM3) The resulting managerial deficiencies became evident, for instance, in the failure to prioritize the different aspects of the projects accordingly. Our informants expressed their fears that IT projects tend to over-promise and underdeliver, despite exceeding their budget. Without the right experience, "you can get seduced by the idea that-oh-if we automate everything it'll be fantastic, when in fact that's wrong" (Global Director, M3). One informant suggested that to avoid such issues, firms need to narrow down the scope of the project into a very specific area. Not all transformation projects were considered to be worth doing. The development costs were often underestimated since the scope and the price of the project would be confirmed only when implementing the project. Thus, our informant suggested that the firms should not enter broadly defined digital transformation projects unless they "have very, very deep pockets" (Former CIO, OEM1). Especially the smaller firms may lack the required financial flexibility.

\subsection{Technological constraints}

Our informants highlighted the role of technological constraints that still exist. To begin with, "it's difficult to get WiFi, GPS, Bluetooth, or any type of wireless signal underground" (Former CIO, OEM1). In turn, as soon as the connectivity can be achieved, critical concerns on the cyber-security arise, since security breaches cause risks for personnel safety and potential significant operational losses. The lack of standardization has complicated the digital transformation process, as integration of all the existing legacy systems needs to be resolved on a case- by-case basis. In many cases, such integration requires cumbersome manual labor. One informant illustrated this by describing how "basically at the end of the day, somebody had to take a USB stick, [...] and to sit there [at the truck] for like five minutes, download the data, and then move." (Former CIO, OEM1).

A surprising perspective to technological constraints arose from the design of the current processes. The mines, and their processes and systems have been designed with human employees in mind. Thus, "having that exact control over something does lead to unforeseen increases in maintenance requirements." (Global Director, M3) To illustrate, the informant described what happened when a mining site replaced the human drivers of their hauling trucks with autonomous software. "Because the trucks travelled exactly on the same path [...] the road got huge ruts [...] where the truck travelled. The road was not being worn down evenly, and so the maintenance on the road actually had to increase because of that." The site had to resolve the issue by imitating human behavior by embedding a small random error to the programmed driving path, to even out the wear on the roads. Such examples illustrate, how "it's extremely important to understand how the machines interact with people" (Senior Managing Director, I1).

The IoT and the legacy systems at the site were difficult to integrate and these contested for popularity. The system providers have been unable to afford sensors that successfully combine the needed robustness and high-detail, quality measurements. Since the new systems were not mature enough to be self-monitoring, mining operators tended to monitor their digital systems manually and uphold their legacy systems as a redundancy measure. The legacy systems were considered more robust, but they were usually not compatible with the new systems. Yet, even if these legacy systems could provide interoperable data, most of these systems and tools could not cope with "millions of lines of data into the analytics" (Head of Automation, M1). Due to various issues in reliability and interoperability, firms have "built in other ways of auditing and [... to have] double or even, in some cases, triple redundancy" (Global Director, M3). The informants concluded that redundancy was inevitable because the IoT systems were technologically immature to withstand the requirements of the mining operations. In general, the existing technology could not be applied in a plug and play fashion to metals and mining industry and further development was considered inevitable.

\subsection{External constraints}


Last, several external constraints were identified to obstruct the digital transformation process. These characteristics became more evident when the organizations were willing and capable to change and had found the potential technological solutions. The defining aspects of these external constraints were that the focal companies had limited, if any, power to influence them. The identified external constraints in our study relate to the operating environment, health and safety, legislation and policies, and social responsibilities.

The most obvious challenges for digital transformation are related to the operating environment in the mining industry. Most of the potential technical solutions, such as smart, connected devices, were not designed to function in the hot, humid, and dirty environment of the mines. These external constraints made it complicated to find or develop the suitable technology, while such constraints were not seen to guide the technology development in other fields.

Next, the health and safety concerns were taken seriously in the field. Robustness, reliability, and safety were required from the systems. Although the mining sites have a reputation of being dangerous, our informants highlighted the role of safety. Surprisingly, safety concerns were used as a reason for not making changes. Senior Manager from I1 described how "especially in the mining industry [...] quite often they [the firms] do put, in front of you this warning sign being the health and safety. We can't do that because of health and safety."

In addition, current legislation and policies did not support the change. The labor unions were seen powerful enough to delay or decline digital transformation projects. The lack of proper coordination between different policies set conflicting incentives for the firms and made it difficult to find the projects with highest priority.

The social responsibility that was set to the firms did not support changes either. The governmental bodies typically considered mining sites as long-term investments, with considerable impacts on the employment at remote locations. In many cases, digital transformation was considered undesirable since it could cause the loss of jobs, while the policymakers had interest to keep the mines operational to secure the national supply of resources. However, despite the desire to support the mines, the environmental impacts of mining have caused societal pressure, which has prevented the investments of public funds to digital transformation projects.

\section{Discussion}

\subsection{Research implications}

Our findings highlight the dependency between market rate of change and dynamic capabilities. The inter-organizational processes, management practices, systems, and other resources and capabilities have been serving their purpose in stable market conditions. The organizational learning and innovation is rather exclusively internally-focused, and the externallyfocused activities of sensing, seizing and transforming the opportunity have a thin foundation [49]. Hence, we conclude that if the historical rate of systemic change in an industry is low, firms lose their dynamic capabilities to change.

Digital transformation extends the scope of activities from the traditional manufacturing related activities to software business related activities, inducing a need to build or gain access to a whole range of novel capabilities and resources, and integrate those capabilities into a value creating activity system. The dependencies within the emerging activity system (such as the connectivity to the underground fleet) between the specialized and co-specialized [47] capabilities and resources determine the sequencing of the development and integration activities, and the internally-induced constraints set boundaries for the scope of change. Clearly, the speed of change favors networked and distributed governance of the new, broader activity system instead of developing those capabilities internally.

Our findings also endorse the sensing, seizing, and transforming framework of dynamic capabilities by providing empirical evidence of the challenges at each stage of the sensing, seizing and re-configuring process. Our findings illustrate how the firms are reluctant to accept the pressure to change, define goals for the transformation, and acquire talent and resources to implement the change.

Finally, the externally-imposed constraints reveal that firms do not change in isolation. Externally, connected firms and other stakeholders (such as labor unions and public policy makers) need to change concurrently. Otherwise, the capability to leverage digital production information for process optimization will offer only limited value, if legislation on data ownership, access, and use is lacking. Internally, digital transformation poses greater demands on resource and capability integration across organizational units, and hence greater demands on dynamic capabilities for aligned and synchronized transformation within and across connected organizations.

\subsection{Managerial implications}


Digitalization in general has attracted a massive amount of attention, and the current expectations are correspondingly high. This article can, however, serve as a reminder that in practice things are never so straightforward. There is a tendency to believe that artificial intelligence, machine learning and IoT will fundamentally redefine the way-of-working in industries $[9,40,41]$. This article, however, shows the other side of the coin, which still involves clear struggles, change resistance and various potential pitfalls for digital transformation processes.

From this study, the firms operating in traditional asset-intensive industries can identify their current situation and the associated constraints concerning digital transformation, and subsequently choose suitable approaches for moving forward. For the partnering companies which participate in such industries' digital transformation, this study pinpoints the underlying challenges and risks. The partnering companies can learn from the outcome, and be more efficient in collaboration and problem-solving with their customers.

Based on the outcomes of this study, we recommend the managers who are driving or about to drive the firm's digital transformation to:

1. Set feasible targets with continuous investments. No matter what the business model, processes and organization structures are like, companies should understand that digital transformation is a lengthy and continuous process which requires a focused strategy, well planned investments, managerial support and encouragement, and to a certain degree, experimentation.

2. Do it with peers. Properly chosen and built partnerships can compensate the companies' missing technology building blocks and capabilities for digitalization in a timely and flexible manner.

3. Take in digital talents. Besides partnership, the firm should build up its own digital capabilities either by acquiring from outside or training internal workforces, to sustain long-term development and achieve maximum value from the digitalization.

4. Focus on "outside-in" innovation to complement the traditional "inside-out" innovation model. Our findings illustrate how the case company struggles to extend their current offering by digitalization. Less attention is dedicated to exploring the customer's world, processes and goals, which ultimately the transformation needs to address.

The metals and mining industry is currently facing several generic challenges such as aging labor force, high operational costs, reduced ore grades and tough operating environments. While it is not a singular allencompassing solution, digital transformation is, nevertheless, considered as an important initiative for overcoming these challenges. We do, therefore, believe that the industry is heading towards the digital era, but reaching this goal requires hard work, investments, wisdom, and patience.

\subsection{Policy implications}

The policy implications of this study are threefold. First of all, successful digital transformation at the institutional level requires initiatives from policy makers on technology standardization, data protection regulations, as well as health and safety guidelines which are fit for the digital era.

Secondly, considering the social responsibility aspect, successful digital transformations may lead to elimination of certain jobs [52]. As discovered in this study, it can lead to tension among companies, labor unions and local governments, which can in turn cause extensive delays to the transformation process. We recommend the associated organizations to keep an open mind towards the transformation, work together to reach a mutual plan, and help workforces who are influenced in the transformation through means such as retraining.

Last but not least, the digital transformation allows to establish reliable and real-time sustainability measures for the metals and mining industry processes. Already, there are many approaches used to measure sustainability [7, 8], Yet, these indicators require data, preferably in large amounts and in good quality. Thus, the digital transformation can enhance the traceability of the environmental impacts and drive the industry to a more sustainable direction. However, the policy makers need to ensure that firms can find it rewarding to disclose their sustainability measures. It is conceivable that the most advanced actors are the first to move in this direction. Since there are no zeroemission mining processes, it is essential that these first-movers gain positive feedback by revealing their data, rather than being exposed to potentially heavy public critique.

\section{Limitations and Future Research}

This study is conducted in the context of a traditional and asset-intensive industry, in specific, metals and mining. We identified several industryrelated constraints such as conservativeness, connectivity difficulties, and strict health and safety requirements. These constraints may not be generalizable to other industries. However, this paper aims to provide a nudge in the appropriate direction. 
Digital transformation triggers formation of new ecosystems. The digital technologies also enable more efficient collaboration among ecosystem partners. To succeed in the transformation, organizations within and across industries should equip themselves with a collaborative mindset, increase information sharing, and work together to optimize the value creation in the ecosystem. Therefore, future research could investigate the ecosystem formation, partner interactions and the impacts to digital transformation. There is an emerging need to investigate how managers apply their dynamic capabilities to develop the specialized and co-specialized capabilities that reside in the connected but separate firms and governance structures.

\section{References}

[1] Allwood, J.M., "Squaring the Circular Economy: The Role of Recycling within a Hierarchy of Material Management Strategies", In E. Worrell and M.A. Reuter, eds., Handbook of Recycling. Elsevier Inc., 2014, 445-477.

[2] Ander, R., and C.E. Helfat, "Corporate Effects and Dynamic Managerial Capabilities", Strategic Management Journal 24, 2003, pp. 1011-1025.

[3] Annunziata, M., and P.C. Evans, "Industrial internet: Pushing the boundaries of minds and machines", General Electric, 2012.

[4] Arica, E., and D.J. Powell, "A framework for ICT-enabled real-time production planning and control", Advances in Manufacturing 2(2), 2014, pp. $158-164$.

[5] Arvidsson, V., J. Holmström, and K. Lyytinen, "Information systems use as strategy practice: A multi-dimensional view of strategic information system implementation and use", Journal of Strategic Information Systems 23(1), 2014, pp. 45-61.

[6] Baden-Fuller, C., and S. Haefliger, "Business models and technological innovation", Long Range Planning 46(6), 2013, pp. 419-426.

[7] Bell, S., and S. Morse, Sustainability indicators: measuring the immeasurable?, Routledge, 2012.

[8] Bennett, M., P. James, and L. Klinkers, Sustainable measures: evaluation and reporting of environmental and social performance, Routledge, 2017.

[9] Berman, S.J., "Digital transformation: opportunities to create new business models", Strategy \& Leadership 40(2), 2012, pp. 16-24.

[10] Borgia, E., "The Internet of Things vision: Key features, applications and open issues", Computer Communications 54, 2014, pp. 1-31.

[11] Bounfour, A., Digital Futures, Digital
Transformation, Springer, 2016.

[12] van Calster, G., "Regulatory Instruments: Sustainable Materials Management, Recycling, and the Law", In E. Worrell and M.A. Reuter, eds., Handbook of Recycling. Elsevier Inc., 2014, 527-535.

[13] Christensen, C.M., T. Bartman, and D. van Bever, "The hard truth about business model innovation", Sloan Management Review 58(1), 2016, pp. 31-40.

[14] Corbin, J., and A. Strauss, Basics of Qualitative Research: Techniques and Procedures for Developing Grounded Theory, SAGE, Thousand Oaks, CA, 2008.

[15] Coreynen, W., P. Matthyssens, and W. Van Bockhaven, "Boosting servitization through digitization: Pathways and dynamic resource configurations for manufacturers", Industrial Marketing Management 60, 2017, pp. 42-53.

[16] Denzin, N.K., and Y.S. Lincoln, "Introduction: Entering the Field of Qualitative Research", In N.K. Denzin and Y.S. Lincoln, eds., Handbook of Qualitative Research. SAGE, Thousand Oaks, CA, 1994, 1-17.

[17] Eaton, B., S. Elaluf-Calderwood, C. Sørensen, and Y. Yoo, "Distributed Tuning of Boundary Resources: The Case of Apple's iOS Service System", MIS Quarterly 39(1), 2015, pp. 217-243.

[18] Eisenhardt, K.M., "Building Theories from Case Study Research.", Academy of Management Review 14(4), 1989, pp. 532-550.

[19] Eisenhardt, K.M., "Building theories from case study research", Academy of Management Review 14(4), 1989, pp. 532-550.

[20] Eisenhardt, K.M., and J.A. Martin, "Dynamic capabilities: what are they?", Strateg. Manag. J. 21, 2000, 1105-1121.

http://www.jstor.org/stable/3094429

[21] Ekka, R., Research Methodology and Data Analysis in Humanities \& Social Sciences, Chatham House London, 2014.

[22] Ernst \& Young, "The digital disconnect: problem or pathway?", 2017, pp. 1-12.

[23] Ernst \& Young, Is riding the digital wave key to wiping out your competition? Mining and Metals, 2018.

[24] European Commission, Digital Economy and Society Index Report 2018- Integration of Digital Technologies, 2017.

[25] Evans, P.C., and A. Gawer, The rise of the platform enterprise: A global survey, 2016.

[26] Foss, N.J., and T. Saebi, "Fifteen years of research on business model innovation: How far have we come, and where should we go?", Journal of Management 43(1), 2017, pp. 200-227.

[27] Gersick, C.T.G., "Revolutionary Change 
Theories : A Multilevel Exploration of the Punctuated Equilibrium Paradigm", The Academy of Management Review 16(1), 1991, pp. 10-36.

[28] Gioia, D.A., K.G. Corley, and A.L. Hamilton, "Seeking Qualitative Rigor in Inductive Research: Notes on the Gioia Methodology", Organizational Research Methods 16(1), 2013, pp. 15-31.

[29] Hakanen, E., V. Eloranta, P. Töytäri, R. Rajala, and T. Turunen, "Material intelligence: Crossorganizational collaboration driven by detailed material data", 50th Hawaii International Conference on System Sciences (HICSS), (2017).

[30] Helfat, C.E., S. Finkelstein, W. Mitchell, et al., Dynamic Capabilities: Understanding Strategic Change in Organizations, Wiley-Blackwell, 2007.

[31] Helfat, C.E., and M.A. Peteraf, "Managerial Cognitive Capabilities and the Microfoundations of Dynamic Capabilities", Strategic Management Journal 36, 2015, pp. 831-850.

[32] Jacobides, M.G., C. Cennamo, and A. Gawer, "Towards a Theory of Ecosystems", Strategic Management Journal, 2018, pp. 804-828.

[33] Kamp, B., and G. Parry, "Servitization and advanced business services as levers for competitiveness", Industrial Marketing Management 60, 2017, pp. 11-16.

[34] Keen, P., and R. Williams, "Value architectures for digital business: beyond the business model", MIS Quarterly 37(2), 2013, pp. 643-648.

[35] Ketokivi, M., and T. Choi, "Renaissance of case research as a scientific method", Journal of Operations Management 32(5), 2014, pp. 232-240.

[36] Mandrella, M., S. Zander, and L.M. Kolbe, "IT-based value co-creation: A literature review and directions for future research", 49th Hawaii International Conference on System Sciences, IEEE (2016), 287-296.

[37] Monostori, L., B. Kádár, T. Bauernhansl, et al., "Cyber-physical systems in manufacturing", CIRP Annals - Manufacturing Technology 65(2), 2016, pp. 621-641.

[38] Ness, D., J. Swift, D.C. Ranasinghe, K. Xing, and V. Soebarto, "Smart steel: New paradigms for the reuse of steel enabled by digital tracking and modelling", Journal of Cleaner Production 98, 2015, pp. 292-303.

[39] Papert, M., and A. Pflaum, "Development of an ecosystem model for the realization of internet of things (IoT) services in supply chain management", Electronic Markets 27, 2017, pp. 175-189.

[40] Porter, M., and J. Heppelmann, "How Smart, Connected Products Are Transforming Competition", Harvard Business Review, 2014, pp. 64-88.

[41] Porter, M.E., and J.E. Heppelmann, "How smart, connected products are transforming companies", Harvard Business Review 2015(October), 2015.

[42] Ragin, C.C., and H.S. Becker, What Is a Case? Exploring the Foundations of Social Inquiry, Cambridge University Press, Cambridge, 1992.

[43] Rajaguru, R., and M.J. Matanda, "Effects of inter-organizational compatibility on supply chain capabilities: Exploring the mediating role of interorganizational information systems (IOIS) integration", Industrial Marketing Management 42(4), 2013, pp. 620-632.

[44] Rajala, R., E. Hakanen, T. Seppälä, J. Mattila, and M. Westerlund, "How do intelligent goods shape closed-loop systems?", California Management Review 60(3), 2018, pp. 20-44.

[45] Reuter, M.A., C. Hudson, A. van Schaik, K. Heiskanen, C. Meskers, and C. Hagelüken, Metal Recycling: Opportunities, Limits, Infrastructure, A Report of the Working Group on the Global Metal Flows to the International Resource Panel, UNEP, 2013.

[46] Rigby, D.K., and S. Tager, Leading a Digical transformation, 2014.

[47] Teece, D.J., "Profiling from technological innovation: implications for integration, collaboration, licencing and public policy", Research Policy 15(February), 1986, pp. 285-305.

[48] Teece, D.J., "Explicating dynamic capabilities: The nature and microfoundations of (sustainable) enterprise performance", Strategic Management Journal 28(13), 2007, pp. 1319-1350.

[49] Teece, D.J., "Explicating dynamic capabilities: The nature and microfoundations of (sustainable) enterprise performance", Strategic Management Journal 28, 2007, pp. 1319-1350.

[50] Töytäri, P., T. Turunen, M. Klein, et al., "Overcoming institutional and capability barriers to smart services", Proceedings of the 50th Hawaii International Conference on System Sciences, 2017, pp. 1642-1651.

[51] Vikström, H., S. Davidsson, and M. Höök, "Lithium availability and future production outlooks", Applied Energy 110, 2013, pp. 252-266.

[52] World Economic Forum/Accenture, "Digital Transformation Initiative Mining and Metals Industry", (January), 2017, pp. 35.

[53] Yin, R.K., Case Study Research: Design and Methods, SAGE, Thousand Oaks, CA, 2009.

[54] Yoo, Y., R.J. Boland, K. Lyytinen, and A. Majchrzak, "Organizing for Innovation in the Digitized World”, Organization Science 23(5), 2012, pp. 1398-1408. 